\title{
Eвponейская конвенция
}

\section{по правам \\ человека}




\section{Европейская}

\section{конвенция}

\section{по правам}

\section{человека}
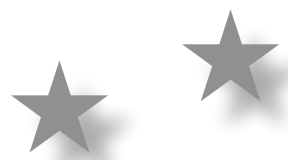

измененная и дополненная Протоколами № 11,14 и 15

в сопровождении Дополнительного протокола и Протоколов № 4, 6, 7, 12, 13 и 16 
Представленный текст Конвенции включает изменения, внесенные в соответствии с положениями Протокола № 15 (СДСЕ № 213), вступившего в силу 1 августа 2021 г. и Протокола № 14 (СДСЕ № 194), вступившего в силу 1 июня 2010 г. Ранее в текст Конвенции были внесены изменения, в соответствии с положениями Протокола № 3 (СТЕ № 45), вступившего в силу с 21 сентября 1970г., Протокола № 5 (СТЕ № 55), вступившегов силус 20 декабря 1971 г.иПротокола №8(СТЕ№118), вступившегов силус 1 января 1990 г. Он включает в себя также текст Протокола № 2 (СТЕ № 44), который, в соответствии с пунктом 3 статьи 5, являлся неотъемлемой частью Конвенции с момента его вступления в силу с 21 сентября 1970 г. Все положения, в которые были внесены изменения или дополнения, согласно вышеуказанным Протоколам, заменены Протоколом № 11 (СTE № 155), с даты его вступления в силу с 1 ноября 1998 года. С этого момента, Протокол № 9 (СТЕ № 140), вступивший в силу с 1 октября 1994г., был отменен, а Протокол № 10 (СТЕ № 146) утратил свою цель.

С информацией о текущем состоянии подписания и ратификации Конвенции и ее протоколов, а также с полным списком заявлений и оговорок можно ознакомиться по адресу www.conventions.coe.int.

Только английская и французская версии Конвенции являются подлинными. Данный перевод не является официальной версией Конвенции.

Европейский суд по правам человека

Council of Europe

67075 Strasbourg cedex

France

www.echr.coe.int

\section{ОГЛАВЛЕНИЕ}

Конвенция о защите прав человека и основных свобод..........

Дополнительный протокол

Протокол № 4

Протокол № 6

Протокол № 7

Протокол № 12

Протокол № 13

Протокол № 16 


\section{Конвенция о защите прав человека и основных свобод}

г. Рим, 4.XI.1950 г.

Правительства, подписавшие настоящую Конвенцию, являющиеся членами Совета Европы,

принимая во внимание Всеобщую декларацию прав человека, провозглашенную Генеральной Ассамблеей Организации Объединенных Наций 10 декабря 1948 года,

учитывая, что эта Декларация имеет целью обеспечить всеобщее и эффективное признание и осуществление провозглашенных в ней прав,

считая, что целью Совета Европы является достижение большего единства между его членами и что одним из средств достижения этой цели является защита и развитие прав человека и основных свобод,

подтверждая свою глубокую приверженность основным свободам, которые являются основой справедливости и всеобщего мира и соблюдение которых наилучшим образом обеспечивается, с одной стороны, подлинно демократическим политическим режимом и, с другой стороны, всеобщим пониманием и соблюдением прав человека, которым они привержены,

преисполненные решимости, как Правительства европейских Государств, движимые единым стремлением и имеющие общее наследие политических традиций, идеалов, свободы и верховенства права, сделать первые шаги на пути обеспечения коллективного осуществления некоторых из прав, изложенных во Всеобщей декларации, 
утверждая, что в соответствии с принципом субсидиарности Высокие Договаривающиеся Стороны несут основную ответственность за соблюдение прав и свобод, гарантированных настоящей Конвенцией и Протоколами к ней, и пользуются при этом свободой усмотрения, находясь под юрисдикционным контролем Европейского суда по правам человека, учрежденного настоящей Конвенцией,

согласились о нижеследующем:

\section{Статья 1}

\section{Обязательство соблюдать права человека}

Высокие Договаривающиеся Стороны обеспечивают каждому, находящемуся под их юрисдикцией, права и свободы, определенные в разделе I настоящей Конвенции.

\section{РАЗДЕЛ I \\ ПРАВА И СВОБОДЫ}

\section{Статья 2}

\section{Право на жизнь}

1. Право каждого лица на жизнь охраняется законом. Никто не может быть умышленно лишен жизни иначе как во исполнение смертного приговора, вынесенного судом за совершение преступления, в отношении которого законом предусмотрено такое наказание.

2. Лишение жизни не рассматривается как нарушение настоящей статьи, когда оно является результатом абсолютно необходимого применения силы:

(а) для защиты любого лица от противоправного насилия; (b) для осуществления законного задержания или предотвращения побега лица, заключенного под стражу на законных основаниях;

(с) для подавления, в соответствии с законом, бунта или мятежа.

\section{Статья 3}

\section{Запрещение пыток}

Никто не должен подвергаться ни пыткам, ни бесчеловечному или унижающему достоинство обращению или наказанию.

\section{Статья 4}

\section{Запрещение рабства и принудительного труда}

1. Никто не должен содержаться в рабстве или подневольном состоянии.

2. Никто не должен привлекаться к принудительному или обязательному труду.

3. Для целей настоящей статьи термин „принудительный или обязательный труд" не включает в себя:

(а) всякую работу, которую обычно должно выполнять лицо, находящееся в заключении согласно положениям статьи 5 настоящей Конвенции или условно освобожденное от такого заключения;

(b) всякую службу военного характера, а в тех странах, в которых правомерным признается отказ от военной службы на основании убеждений, службу, назначенную вместо обязательной военной службы;

(c) всякую службу, обязательную в случае чрезвычайного положения или бедствия, угрожающего жизни или благополучию населения; 
(d) всякую работу или службу, являющуюся частью обычных гражданских обязанностей.

\section{Статья 5}

\section{Право на свободу и личную неприкосновенность}

1. Каждый имеет право на свободу и личную неприкосновенность. Никто не может быть лишен свободы иначе как в следующих случаях и в порядке, установленном законом:

(а) законное содержание под стражей лица, осужденного компетентным судом;

(b) законное задержание или заключение под стражу (арест) лица за неисполнение вынесенного в соответствии с законом решения суда или с целью обеспечения исполнения любого обязательства, предписанного законом;

(c) законное задержание или заключение под стражу лица, произведенное с тем, чтобы оно предстало перед компетентным органом по обоснованному подозрению в совершении правонарушения или в случае, когда имеются достаточные основания полагать, что необходимо предотвратить совершение им правонарушения или помешать ему скрыться после его совершения;

(d) заключение под стражу несовершеннолетнего лица на основании законного постановления для воспитательного надзора или его законное заключение под стражу, произведенное с тем, чтобы оно предстало перед компетентным органом;

(е) законное заключение под стражу лиц с целью предотвращения распространения инфекционных заболеваний, а также законное заключение под стражу душевнобольных, алкоголиков, наркоманов или бродяг; (f) законное задержание или заключение под стражу лица с целью предотвращения его незаконного въезда в страну или лица, против которого принимаются меры по его высылке или выдаче.

2. Каждому арестованному незамедлительно сообщаются на понятном ему языке причины его ареста и любое предъявляемое ему обвинение.

3. Каждый задержанный или заключенный под стражу в соответствии С подпунктом "С" пункта 1 настоящей статьи незамедлительно доставляется к судье или к иному должностному лицу, наделенному, согласно закону, судебной властью, и имеет право на судебное разбирательство в течение разумного срока или на освобождение до суда. Освобождение может быть обусловлено предоставлением гарантий явки в суд.

4. Каждый, кто лишен свободы в результате ареста или заключения под стражу, имеет право на безотлагательное рассмотрение судом правомерности его заключения под стражу и на освобождение, если его заключение под стражу признано судом незаконным.

5. Каждый, кто стал жертвой ареста или заключения под стражу в нарушение положений настоящей статьи, имеет право на компенсацию.

\section{Статья 6}

\section{Право на справедливое судебное разбирательство}

1. Каждый в случае спора о его гражданских правах и обязанностях или при предъявлении ему любого уголовного обвинения имеет право на справедливое и публичное разбирательство дела в разумный срок независимым и беспристрастным судом, созданным на основании закона. Судебное решение объявляется публично, однако пресса и публика могут не допускаться на судебные заседания в течение всего процесса или его части по соображениям морали, 
общественного порядка или национальной безопасности в демократическом обществе, а также когда того требуют интересы несовершеннолетних или для защиты частной жизни сторон, или - в той мере, в какой это, по мнению суда, строго необходимо - при особых обстоятельствах, когда гласность нарушала бы интересы правосудия.

2. Каждый обвиняемый в совершении уголовного преступления считается невиновным, до тех пор пока его виновность не будет установлена законным порядком.

3. Каждый обвиняемый в совершении уголовного преступления имеет как минимум следующие права:

(а) быть незамедлительно и подробно уведомленным на понятном ему языке о характере и основании предъявленного ему обвинения;

(b) иметь достаточное время и возможности для подготовки своей защиты;

(c) защищать себя лично или через посредство выбранного им самим защитника или, при недостатке у него средств для оплаты услуг защитника, пользоваться услугами назначенного ему защитника бесплатно, когда того требуют интересы правосудия;

(d) допрашивать показывающих против него свидетелей или иметь право на то, чтобы эти свидетели были допрошены, и иметь право на вызов и допрос свидетелей в его пользу на тех же условиях, что и для свидетелей, показывающих против него;

(е) пользоваться бесплатной помощью переводчика, если он не понимает языка, используемого в суде, или не говорит на этом языке.

\section{Статья 7 \\ Наказание исключительно на основании закона}

1. Никто не может быть осужден за совершение какого-либо деяния или за бездействие, которое согласно действовавшему в момент его совершения национальному или международному праву не являлось уголовным преступлением. Не может также налагаться наказание более тяжкое, нежели то, которое подлежало применению в момент совершения уголовного преступления.

2. Настоящая статья не препятствует осуждению и наказанию любого лица за совершение какого-либо деяния или за бездействие, которое в момент его совершения являлось уголовным преступлением в соответствии с общими принципами права, признанными цивилизованными странами.

\section{Статья 8}

\section{Право на уважение частной и семейной жизни}

1. Каждый имеет право на уважение его личной и семейной жизни, его жилища и его корреспонденции.

2. Не допускается вмешательство со стороны публичных властей в осуществление этого права, за исключением случаев, когда такое вмешательство предусмотрено законом и необходимо в демократическом обществе в интересах национальной безопасности и общественного порядка, экономического благосостояния страны, в целях предотвращения беспорядков или преступлений, для охраны здоровья или нравственности или защиты прав и свобод других лиц.

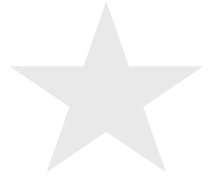

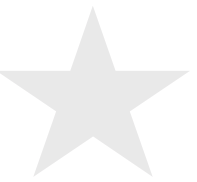




\section{Статья 9}

\section{Свобода мысли, совести и религии}

1. Каждый имеет право на свободу мысли, совести и религии; это право включает свободу менять свою религию или убеждения и свободу исповедовать свою религию или убеждения как индивидуально, так и сообща с другими, публичным или частным порядком в богослужении, обучении, отправлении религиозных и культовых обрядов.

2. Свобода исповедовать свою религию или убеждения подлежит лишь тем ограничениям, которые предусмотрены законом и необходимы в демократическом обществе в интересах общественной безопасности, для охраны общественного порядка, здоровья или нравственности или для защиты прав и свобод других лиц.

\section{Статья 10}

\section{Свобода выражения мнения}

1. Каждый имеет право свободно выражать свое мнение. Это право включает свободу придерживаться своего мнения и свободу получать и распространять информацию и идеи без какого-либо вмешательства со стороны публичных властей и независимо от государственных границ. Настоящая статья не препятствует Государствам осуществлять лицензирование радиовещательных, телевизионных или кинематографических предприятий.

2. Осуществление этих свобод, налагающее обязанности и ответственность, может быть сопряжено с определенными формальностями, условиями, ограничениями или санкциями, которые предусмотрены законом и необходимы в демократическом обществе в интересах национальной безопасности, территориальной целостности или общественного порядка, в целях предотвращения беспорядков или преступлений, для охраны здоровья и нравственности, защиты репутации или прав других лиц, предотвращения разглашения информации, полученной конфиденциально, или обеспечения авторитета и беспристрастности правосудия.

\section{Статья 11}

\section{Свобода собраний и объединений}

1. Каждый имеет право на свободу мирных собраний и на свободу объединения с другими, включая право создавать профессиональные союзы и вступать в таковые для защиты своих интересов.

2. Осуществление этих прав не подлежит никаким ограничениям, кроме тех, которые предусмотрены законом и необходимы в демократическом обществе в интересах национальной безопасности и общественного порядка, в целях предотвращения беспорядков и преступлений, для охраны здоровья и нравственности или защиты прав и свобод других лиц. Настоящая статья не препятствует введению законных ограничений на осуществление этих прав лицами, входящими в состав вооруженных сил, полиции или административных органов Государства.

\section{Статья 12}

\section{Право на вступление в брак}

Мужчины и женщины, достигшие брачного возраста, имеют право вступать в брак и создавать семью в соответствии с национальным законодательством, регулирующим осуществление этого права. 


\section{Статья 13}

\section{Право на эффективное средство правовой защиты}

Каждый, чьи права и свободы, признанные в настоящей Конвенции, нарушены, имеет право на эффективное средство правовой защиты в государственном органе, даже если это нарушение было совершено лицами, действовавшими в официальном качестве.

\section{Статья 14}

\section{Запрещение дискриминации}

Пользование правами и свободами, признанными в настоящей Конвенции, должно быть обеспечено без какой бы то ни было дискриминации по признаку пола, расы, цвета кожи, языка, религии, политических или иных убеждений, национального или социального происхождения, принадлежности к национальным меньшинствам, имущественного положения, рождения или по любым иным признакам.

\section{Статья 15}

\section{Отступление от соблюдения обязательств}

\section{в чрезвычайных ситуациях}

1. Вслучаевойныилиприиныхчрезвычайныхобстоятельствах, угрожающих жизни нации, любая из Высоких Договаривающихся Сторон может принимать меры в отступление от ее обязательств по настоящей Конвенции только в той степени, в какой это обусловлено чрезвычайностью обстоятельств, при условии, что такие меры не противоречат другим ее обязательствам по международному праву.

2. Это положение не может служить основанием для какого бы то ни было отступления от положений статьи 2, за исключением случаев гибели людей в результате правомерных военных действий, или от положений статьи 3, пункта 1 статьи 4 и статьи 7.
3. Любая из Высоких Договаривающихся Сторон, использующая это право отступления, исчерпывающим образом информирует Генерального секретаря Совета Европы о введенных ею мерах и о причинах их принятия. Она также ставит в известность Генерального секретаря Совета Европы о дате прекращения действия таких мер и возобновлении осуществления положений Конвенции в полном объеме.

\section{Статья 16}

\section{Ограничение на политическую деятельность иностранцев}

Ничто в статьях 10, 11 и 14 не может рассматриваться как препятствие для Высоких Договаривающихся Сторон вводить ограничения на политическую деятельность иностранцев.

\section{Статья 17}

\section{Запрещение злоупотреблений правами}

Ничто в настоящей Конвенции не может толковаться как означающее, что какое-либо Государство, какая-либо группа лиц или какое-либо лицо имеет право заниматься какой бы то ни было деятельностью или совершать какие бы то ни было действия, направленные на упразднение прав и свобод, признанных в настоящей Конвенции, или на их ограничение в большей мере, чем это предусматривается в Конвенции.

\section{Статья 18}

Пределы использования ограничений в отношении прав

Ограничения, допускаемые в настоящей Конвенции в отношении указанных прав и свобод, не должны применяться для иных целей, нежели те, для которых они были предусмотрены. 


\section{РАЗДЕЛ II ЕВРОПЕЙСКИЙ СУД ПО ПРАВАМ ЧЕЛОВЕКА}

\section{Статья 19}

\section{Учреждение Суда}

В целях обеспечения соблюдения обязательств, принятых на себя Высокими Договаривающимися Сторонами по настоящей Конвенции и Протоколам к ней, учреждается Европейский суд по правам человека, далее именуемый „Суд". Он работает на постоянной основе.

\section{Статья 20}

Число судей

Число судей, входящих в состав Суда, равно числу Высоких Договаривающихся Сторон.

\section{Статья 21}

\section{Предъявляемые к судьям требования}

1. Судьи должны обладать самыми высокими моральными качествами и удовлетворять требованиям, предъявляемым при назначении на высокие судебные должности, или быть правоведами с общепризнанным авторитетом.

2. Кандидатам должно быть менее 65 лет на дату, к которой Парламентской ассамблее должен быть представлен список из трех кандидатов согласно статье 22.

3. Судьи участвуют в работе Суда в личном качестве.

4. На протяжении всего срока пребывания в должности судьи не должны осуществлять никакой деятельности, несовместимой с их независимостью, беспристрастностью или с требованиями, вытекающими из характера их работы в течение полного рабочего дня. Все вопросы, возникающие в связи с применением положений настоящего пункта, решаются Судом.

\section{Статья 22}

\section{Выборы судей}

Судья от каждой из Высоких Договаривающихся Сторон избирается Парламентской ассамблеей большинством поданных за него голосов из списка, включающего трех кандидатов, представляемых этой Высокой Договаривающейся Стороной.

\section{Статья 23}

\section{Срок полномочий и освобождение от должности}

1. Судьи избираются сроком на девять лет. Они не могут быть переизбраны.

2. Судьи занимают свои посты вплоть до замены. Вместе с тем и после замены они продолжают рассматривать уже поступившие к ним дела.

3. Судья может быть освобожден от должности только в случае, если остальные судьи большинством в две трети голосов принимают решение о том, что данный судья перестает соответствовать предъявляемым требованиям.

\section{Статья 24}

\section{Секретариат и докладчики}

1. У Суда имеется Секретариат, права, обязанности и организация которого определяются Регламентом Суда.

2. Когда Суд заседает в составе единоличного судьи, Суд пользуется услугами докладчиков, которые осуществляют свои функции под руководством Председателя Суда. Они образуют подразделение Секретариата Суда. 


\section{Статья 25}

\section{Пленарные заседания Суда}

На пленарных заседаниях Суд:

(а) избирает своего Председателя и одного или двух заместителей Председателя сроком на три года; они могут быть переизбраны;

(b) образует Палаты, создаваемые на определенный срок;

(c) избирает Председателей Палат Суда; они могут быть переизбраны;

(d) принимает Регламент Суда;

(e) избирает Секретаря-канцлера Суда и одного или нескольких его заместителей;

(f) представляет какое-либо ходатайство в соответствии с пунктом 2 статьи 26.

\section{Статья 26}

\section{Единоличные судьи, комитеты,} Палаты и Большая Палата

1. Для рассмотрения переданных ему дел Суд заседает в составе единоличного судьи, комитетов из трех судей, Палат из семи судей и Большой Палаты из семнадцати судей. Палаты Суда на определенный срок образуют комитеты.

2. По ходатайству пленарного заседания Суда Комитет Министров вправе своим единогласным решением на определенный срок уменьшить число судей в составе Палат до пяти.

3. Заседая по делу единолично, судья не вправе рассматривать никакую жалобу, поданную против Высокой Договаривающейся Стороны, от которой этот судья избран.

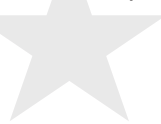

4. Судья, избранный от Высокой Договаривающейся Стороны, выступающей стороной в споре, заседает по делу как ex officio член Палаты и Большой Палаты. В случае отсутствия такого судьи или если он не может участвовать в заседании, в качестве судьи по делу заседает лицо, назначенное Председателем Суда из списка, заблаговременно представленного этой Стороной.

5. В состав Большой Палаты входят также Председатель Суда, заместители Председателя Суда, Председатели Палат и другие члены Суда, назначенные в соответствии с Регламентом Суда. В тех случаях, когда дело передается в Большую Палату в соответствии с положениями статьи 43, в ее заседаниях не вправе участвовать ни один из судей Палаты, вынесшей постановление, за исключением Председателя этой Палаты и судьи, избранного от Высокой Договаривающейся Стороны, выступающей стороной в споре.

\section{Статья 27}

\section{Компетенция единоличных судей}

1. Единоличный судья вправе объявить неприемлемой жалобу, поданную в соответствии со статьей 34 , или исключить ее из списка подлежащих рассмотрению Судом дел, если таковое решение может быть принято без дополнительного изучения жалобы.

2. Это решение является окончательным.

3. Если единоличный судья не объявляет неприемлемой жалобу или не исключает ее из списка подлежащих рассмотрению дел, то этот судья направляет ее в комитет или Палату для дополнительного изучения. 


\section{Статья 28}

\section{Компетенция комитетов}

1. В отношении жалобы, поданной в соответствии со статьей 34, комитет вправе единогласным решением:

(а) объявить ее неприемлемой или исключить ее из списка подлежащих рассмотрению дел, если таковое решение может быть принято без дополнительного изучения жалобы; или

(b) объявить ее приемлемой и одновременно вынести постановление по существу жалобы, если лежащий в основе дела вопрос, касающийся толкования или применения положений настоящей Конвенции либо Протоколов к ней, уже является предметом прочно утвердившегося прецедентного права Суда.

2. Решения и постановления, принимаемые в соответствии с пунктом 1, являются окончательными.

3. Если судья, избранный от Высокой Договаривающейся Стороны, выступающей стороной в споре, не является членом комитета, последний вправе на любой стадии производства по делу предложить этому судье заместить одного из членов комитета, учитывая при этом все имеющие отношение к делу факторы, включая вопрос, оспаривала ли эта Сторона применение процедуры, предусмотренной подпунктом «b» пункта 1.

\section{Статья 29}

\section{Решения Палат}

\section{о приемлемости жалобы и по существу дела}

1. Если не было принято никакого решения в соответствии с положениями статей 27 или 28 или не было вынесено никакого постановления в соответствии с положениями статьи 28, Палата выносит решение о приемлемости и по существу индивидуальных жалоб, поданных в соответствии с положениями статьи 34. Решение о приемлемости жалобы может быть вынесено отдельно.

2. Палата выносит решение о приемлемости жалобы Государства, поданной в соответствии со статьей 33, и по существу дела. Решение о приемлемости жалобы принимается отдельно, если только Суд, в исключительных случаях, не примет решение об обратном.

\section{Статья 30}

\section{Уступка юрисдикции в пользу Большой Палаты}

Если дело, находящееся на рассмотрении Палаты, затрагивает серьезный вопрос, касающийся толкования положений Конвенции или Протоколов к ней, или если решение вопроса может войти в противоречие с ранее вынесенным Судом постановлением, Палата может до вынесения своего постановления уступить юрисдикцию в пользу Большой Палаты.

\section{Статья 31}

\section{Полномочия Большой Палаты}

Большая Палата:

(a) выносит решения по жалобам, поданным в соответствии со статьей 33 или статьей 34 , когда какаялибо из Палат уступила юрисдикцию на основании положений статьи 30 или когда дело направлено ей в соответствии с положениями статьи 43;

(b) принимает решения по вопросам, переданным на рассмотрение Суда Комитетом Министров в соответствии с пунктом 4 статьи 46; и

(c) рассматривает запросы о вынесении консультативных заключений, направленные в соответствии с положениями статьи 47. 


\section{Статья 32}

\section{Компетенция Суда}

1. В ведении Суда находятся все вопросы, касающиеся толкования и применения положений Конвенции и Протоколов к ней, которые могут быть ему переданы в случаях, предусмотренных положениями статей 33, 34, 46 и 47.

2. В случае спора относительно компетенции Суда по конкретному делу вопрос решает сам Суд.

\section{Статья 33}

\section{Межгосударственные дела}

Любая Высокая Договаривающаяся Сторона может передать В Суд вопрос о любом предполагаемом нарушении положений Конвенции и Протоколов к ней другой Высокой Договаривающейся Стороной.

\section{Статья 34}

\section{Индивидуальные жалобы}

Суд может принимать жалобы от любого физического лица, любой неправительственной организации или любой группы частных лиц, которые утверждают, что явились жертвами нарушения одной из Высоких Договаривающихся Сторон их прав, признанных в настоящей Конвенции или в Протоколах к ней. Высокие Договаривающиеся Стороны обязуются никоим образом не препятствовать эффективному осуществлению этого права.

\section{Статья 35}

\section{Условия приемлемости}

1. Суд может принимать дело к рассмотрению только после того, как были исчерпаны все внутренние средства правовой защиты, как это предусмотрено общепризнанными нормами международного права, и в течение четырех месяцев с даты вынесения национальными органами окончательного решения по делу.

2. Суднепринимает к рассмотрениюникакую индивидуальную жалобу, поданную в соответствии со статьей 34, если она:

(а) является анонимной; или

(b) является по существу аналогичной той, которая уже была рассмотрена Судом, или уже является предметом другой процедуры международного разбирательства или урегулирования, и если она не содержит новых относящихся к делу фактов.

3. Суд объявляет неприемлемой любую индивидуальную жалобу, поданную в соответствии с положениями статьи 34, если он сочтет, что:

(а) эта жалоба является несовместимой с положениями настоящей Конвенции или Протоколов к ней, явно необоснованной или является злоупотреблением правом подачи индивидуальной жалобы; или

(b) заявитель не понес значительный ущерб, если только принцип уважения прав человека, как они определены в настоящей Конвенции и Протоколах к ней, не требует рассмотрения жалобы по существу.

4. Суд отклоняет любую переданную ему жалобу, которую сочтет неприемлемой в соответствии с настоящей статьей. Он может сделать это на любой стадии разбирательства.

\section{Статья 36}

\section{Участие третьей стороны}

1. В отношении любого дела, находящегося на рассмотрении какой-либо из Палат или Большой Палаты, каждая Высокая Договаривающаяся сторона, гражданин которой является заявителем, вправе представлять письменные замечания и принимать участие в слушаниях. 
2. В интересах надлежащего отправления правосудия Председатель Суда может пригласить любую Высокую Договаривающуюся Сторону, не являющуюся стороной в деле или любое заинтересованное лицо, не являющееся заявителем, представить письменные замечания или принять участие в слушаниях.

3. В отношении любого дела, находящегося на рассмотрении какой-либо из Палат или Большой Палаты, Комиссар Совета Европы по правам человека вправе представлять письменные замечания и принимать участие в слушаниях.

\section{Статья 37}

\section{Прекращение производства по делу}

1. Суд может на любой стадии разбирательства принять решение о прекращении производства по делу, если обстоятельства позволяют сделать вывод о том, что:

(а) заявитель более не намерен добиваться рассмотрения своей жалобы; или

(b) спор был урегулирован; или

(c) по любой другой причине, установленной Судом, если дальнейшее рассмотрение жалобы является неоправданным.

Тем не менее, Суд продолжает рассмотрение жалобы, если этого требует соблюдение прав человека, гарантированных настоящей Конвенцией и Протоколами к ней.

2. Суд может принять решение восстановить жалобу в списке подлежащих рассмотрению дел, если сочтет, что это оправдано обстоятельствами.

\section{Статья 38}

\section{Порядок рассмотрения дела}

Суд рассматривает дело с участием представителей сторон и, если это необходимо, предпринимает расследование обстоятельств дела, для эффективного проведения которого участвующие в нем Высокие Договаривающиеся Стороны создают все необходимые условия.

\section{Статья 39}

\section{Мировые соглашения}

1. На любой стадии производства по делу Суд вправе предоставить себя в распоряжение заинтересованных сторон с целью заключения мирового соглашения по делу на основе уважения прав человека, как они определены в настоящей Конвенции и Протоколах к ней.

2. Процедура, осуществляемая в соответствии с пунктом 1, носит конфиденциальный характер.

3. В случае заключения мирового соглашения Суд исключает дело из своего списка посредством вынесения решения, в котором дается лишь краткое изложение фактов и достигнутого разрешения спора.

4. Это решение направляется Комитету Министров, который осуществляет надзор за выполнением условий мирового соглашения, как они изложены в решении.

\section{Статья 40}

\section{Открытые судебные заседания и доступ к документам}

1. Если в силу исключительных обстоятельств Суд не примет иного решения, его заседания являются открытыми. 
2. Доступ к документам, переданным на хранение в Секретариат, открыт для публики, если Председатель Суда не примет иного решения.

\section{Статья 41}

\section{Справедливая компенсация}

Если Суд объявляет, что имело место нарушение Конвенции или Протоколов к ней, а внутреннее право Высокой Договаривающейся Стороны допускает возможность лишь частичного устранения последствий этого нарушения, Суд, в случае необходимости, присуждает справедливую компенсацию потерпевшей стороне.

\section{Статья 42}

\section{Постановления Палат}

Постановления Палат становятся окончательными в соответствии с положениями пункта 2 статьи 44.

\section{Статья 43}

\section{Передача дела в Большую Палату}

1. В течение трех месяцев с даты вынесения Палатой постановления в исключительных случаях возможно обращение любой из сторон в деле о передаче его на рассмотрение Большой Палаты.

2. Коллегия в составе пяти членов Большой Палаты принимает обращение, если дело поднимает серьезный вопрос, касающийся толкования или применения положений настоящей Конвенции или Протоколов к ней, или другой серьезный вопрос общего характера.

3. Если Коллегия принимает обращение, то Большая Палата выносит по делу свое постановление.

\section{Статья 44}

\section{Окончательные постановления}

1. Постановление Большой Палаты является окончательным.

2. Постановление любой из Палат становится окончательным, если:

(a) стороны не заявляют, что они будут просить о передаче дела в Большую Палату; или

(b) по истечении трех месяцев с даты вынесения постановления не поступило обращения о передаче дела в Большую Палату; или

(c) Коллегия Большой Палаты отклоняет обращение о передаче дела согласно статье 43.

3. Окончательное постановление подлежит публикации.

\section{Статья 45}

\section{Мотивировка постановлений и решений}

1. Постановления, а также решения о приемлемости или неприемлемости жалоб должны быть мотивированными.

2. Если постановление в целом или частично не выражает единогласного мнения судей, то любой судья вправе представить свое особое мнение.

\section{Статья 46}

\section{Обязательная сила и исполнение постановлений}

1. Высокие Договаривающиеся Стороны обязуются исполнять окончательные постановления Суда по любому делу, в котором они выступают сторонами.

2. Окончательное постановление Суда направляется Комитету министров, который осуществляет надзор за его исполнением. 
3. Если Комитет Министров считает, что надзору за исполнением окончательного постановления препятствует проблема толкования этого постановления, он вправе передать данный вопрос на рассмотрение Суда для вынесения им постановления по вопросу толкования. Решение о передаче вопроса на рассмотрение Суда требует большинства голосов в две трети от числа представителей, управомоченных принимать участие в работе Комитета.

4. Если Комитет Министров считает, что Высокая Договаривающаяся Сторона отказывается подчиниться окончательному постановлению по делу, в котором она выступает стороной, он вправе, после направления официального уведомления этой Стороне, и путем принятия решения большинством голосов в две трети от числа представителей, управомоченных принимать участие в работе Комитета, передать на рассмотрение Суда вопрос, не нарушила ли эта Сторона свое обязательство, установленное в соответствии с пунктом 1.

5. Если Суд устанавливает факт нарушения пункта 1, он передает дело в Комитет Министров для рассмотрения мер, подлежащих принятию. Если Суд не устанавливает факт нарушения пункта 1, он передает дело в Комитет Министров, который закрывает рассмотрение дела.

\section{Статья 47}

\section{Консультативные заключения}

1. Суд может по просьбе Комитета министров выносить консультативные заключения по юридическим вопросам, касающимся толкования положений Конвенции и Протоколов к ней.

2. Такие заключения не должны затрагивать ни вопросы, относящиеся к содержанию или объему прав или свобод, определенных в Разделе I Конвенции и Протоколах к ней, ни другие вопросы, которые Суду или Комитету министров, возможно, потребовалось бы затронуть при рассмотрении какого-либо обращения, предусмотренного Конвенцией.

3. Решение Комитета министров запросить консультативное заключение Суда принимается большинством голосов представителей, имеющих право заседать в Комитете.

\section{Статья 48}

\section{Компетенция Суда в отношении консультативных заключений}

Вопрос о том, относится ли направленный Комитетом министров запрос о вынесении консультативного заключения к компетенции Суда, как она определена в статье 47, решает Суд.

\section{Статья 49}

\section{Мотивировка консультативных заключений}

1. Консультативные заключения Суда должны быть мотивированными.

2. Если консультативное заключение в целом или частично не выражает единогласного мнения судей, то любой судья вправе представить свое особое мнение.

3. Консультативное заключение Суда направляется Комитету министров.

\section{Статья 50}

\section{Расходы на содержание Суда}

Расходы, связанные с деятельностью Суда, несет Совет Европы. 


\section{Статья 51}

\section{Привилегии и иммунитеты Судей}

Судьи при исполнении своих функций пользуются привилегиями и иммунитетами, предусмотренными статьей 40 Устава Совета Европы и в соглашениях, заключенных на ее основе.

\section{РАЗДЕЛ III \\ РАЗЛИЧНЫЕ ПОЛОЖЕНИЯ}

\section{Статья 52}

\section{Запросы Генерального секретаря}

По получении просьбы от Генерального секретаря Совета Европы каждая Высокая Договаривающаяся Сторона представляет разъяснения относительно того, каким образом ее внутреннее право обеспечивает эффективное применение любого из положений настоящей Конвенции.

\section{Статья 53}

\section{Гарантии в отношении признанных прав человека}

Ничто в настоящей Конвенции не может быть истолковано как ограничение или умаление любого из прав человека и основных свобод, которые могут обеспечиваться законодательством любой Высокой Договаривающейся Стороны или любым иным соглашением, в котором она участвует.

\section{Статья 54}

\section{Полномочия Комитета министров}

Ничто в настоящей Конвенции не умаляет полномочий Комитета министров, которыми он наделен в силу Устава Совета Европы.

\section{Статья 55}

\section{Отказ от иных средств урегулирования споров}

Высокие Договаривающиеся Стороны согласны, если иное не установлено особым соглашением, не прибегать к действующим между ними договорам, конвенциям или декларациям при передаче на рассмотрение, путем направления заявления, спора по поводу толкования или применения положений настоящей Конвенции и не использовать иные средства урегулирования спора, чем предусмотренные настоящей Конвенцией.

\section{Статья 56}

\section{Территориальная сфера действия}

1. Любое Государство при ратификации или впоследствии может заявить путем уведомления Генерального секретаря Совета Европы о том, что настоящая Конвенция, с учетом пункта 4 настоящей статьи, распространяется на все территории или на любую из них, за внешние сношения которых оно несет ответственность.

2. Действие Конвенции распространяется на территорию или территории, указанные в уведомлении, с тридцатого дня после получения Генеральным секретарем Совета Европы этого уведомления.

3. Положения настоящей Конвенции применяются на упомянутых территориях с надлежащим учетом местных условий.

4. Любое Государство, которое сделало заявление в соответствии с пунктом 1 настоящей статьи, может впоследствии в любое время заявить, применительно к одной или нескольким территориям, указанным в этом заявлении, о признании компетенции Суда принимать жалобы от физических лиц, неправительственных организаций или групп частных лиц, как это предусмотрено статьей 34 Конвенции. 


\section{Статья 57}

\section{Оговорки}

1. Любое Государство при подписании настоящей Конвенции или при сдаче им на хранение его ратификационной грамоты может сделать оговорку к любому конкретному положению Конвенции в отношении того, что тот или иной закон, действующий в это время на его территории, не соответствует этому положению. В соответствии с настоящей статьей оговорки общего характера не допускаются.

2. Любая оговорка, сделанная в соответствии с настоящей статьей, должна содержать краткое изложение соответствующего закона.

\section{Статья 58}

\section{Денонсация}

1. Высокая Договаривающаяся Сторона может денонсировать настоящую Конвенцию только по истечении пяти лет с даты, когда она стала Стороной Конвенции, и по истечении шести месяцев после направления уведомления Генеральному секретарю Совета Европы, который информирует об этом другие Высокие Договаривающиеся Стороны.

2. Денонсация не освобождает соответствующую Высокую Договаривающуюся Сторону от ее обязательств по настоящей Конвенции в отношении любого действия, котороемогло явиться нарушением таких обязательств и могло быть совершено ею до даты вступления денонсации в силу.

3. Любая Высокая Договаривающаяся Сторона, которая перестает быть членом Совета Европы, на тех же условиях перестает быть и Стороной настоящей Конвенции.

4. Конвенция может быть денонсирована в соответствии с положениями предыдущих пунктов в отношении любой территории, на которую распространялось ее действие согласно положениям статьи 56.

\section{Статья 59}

\section{Подписание и ратификация}

1. Настоящая Конвенция открыта для подписания Государствами - членами Совета Европы. Она подлежит ратификации. Ратификационные грамоты сдаются на хранение Генеральному секретарю Совета Европы.

2. Европейский Союз вправе присоединиться к настоящей Конвенции.

3. Настоящая Конвенция вступает в силу после сдачи на хранение десяти ратификационных грамот.

4. Для тех Государств, которые ратифицируют Конвенцию впоследствии, она вступает в силу с даты сдачи ими на хранение их ратификационных грамот.

5. Генеральный секретарь Совета Европы уведомляет все Государства - члены Совета Европы о вступлении Конвенции в силу, о Высоких Договаривающихся Сторонах, ратифицировавших ее, и о сдаче ратификационных грамот, которые могут быть получены впоследствии.

Совершено в Риме 4 ноября 1950 года на английском и французском языках, причем оба текста имеют одинаковую силу, в единственном экземпляре, который хранится в архиве Совета Европы. Генеральный секретарь направляет заверенные копии всем подписавшим Конвенцию Государствам. 


\section{Дополнительный протокол}

\section{к Конвенции о защите прав человека и основных свобод}

\author{
г. Париж, 20.III.1952 г.
}

Правительства, подписавшие настоящий Протокол, являющиеся членами Совета Европы,

преисполненные решимости принять меры по обеспечению коллективного осуществления некоторых прав и свобод помимо тех, которые уже включены в Раздел 1 Конвенции о защите прав человека и основных свобод, подписанной в Риме 4 ноября 1950 года (далее именуемой „Конвенция“), согласились о нижеследующем:

\section{Статья 1}

\section{Защита собственности}

Каждое физическое или юридическое лицо имеет право на уважение своей собственности. Никто не может быть лишен своего имущества иначе как в интересах общества и на условиях, предусмотренных законом и общими принципами международного права.

Предыдущие положения не умаляют права Государства обеспечивать выполнение таких законов, какие ему представляются необходимыми для осуществления контроля за использованием собственности в соответствии с общими интересами или для обеспечения уплаты налогов или других сборов или штрафов.

\section{Статья 2}

\section{Право на образование}

Никому не может быть отказано в праве на образование. Государство при осуществлении функций, которые оно принимает на себя в области образования и обучения, уважает право родителей обеспечивать такое образование и такое обучение, которые соответствуют их религиозным и философским убеждениям.

\section{Статья 3}

\section{Право на свободные выборы}

Высокие Договаривающиеся Стороны обязуются проводить с разумной периодичностью свободные выборы путем тайного голосования в таких условиях, которые обеспечивали бы свободное волеизъявление народа при выборе органов законодательной власти.

\section{Статья 4}

\section{Территориальная сфера действия}

Любая Высокая Договаривающаяся Сторона может при подписании или ратификации или в любое время впоследствии направить Генеральному секретарю Совета Европы заявление о пределах своих обязательств относительно применения положений настоящего Протокола к тем указанным в заявлении территориям, за внешние сношения которых она несет ответственность.

Любая Высокая Договаривающаяся Сторона, направившая заявление в соответствии с положениями предыдущего пункта, может время от времени направлять новое заявление об изменении условий любого предыдущего заявления или о 
прекращении применения положений настоящего Протокола в отношении какой-либо территории.

Заявление, сделанное в соответствии с положениями настоящей статьи, рассматривается как сделанное в соответствии с пунктом 1 статьи 56 Конвенции.

\section{Статья 5}

\section{Соотношение с Конвенцией}

Высокие Договаривающиеся Стороны рассматривают статьи 1, 2, 3 и 4 настоящего Протокола как дополнительные статьи к Конвенции, и все положения Конвенции применяются соответственно.

\section{Статья 6}

\section{Подписание и ратификация}

Настоящий Протокол открыт для подписания Государствами - членами Совета Европы, подписавшими Конвенцию. Он подлежит ратификации одновременно с ратификацией Конвенции или после таковой. Протокол вступает в силу после сдачи на хранение десяти ратификационных грамот. В отношении каждого подписавшего Государства, которое ратифицирует Протокол впоследствии, он вступает в силу с даты сдачи им на хранение его ратификационной грамоты.

Ратификационные грамоты сдаются на хранение Генеральному секретарю Совета Европы, который уведомляет все Государства - члены Совета Европы о Государствах, ратифицировавших Протокол.

Совершено в Париже 20 марта 1952 года на английском и французском языках, причем оба текста имеют одинаковую силу, в единственном экземпляре, который хранится в архиве Совета Европы. Генеральный секретарь направляет заверенную копию каждому Правительству, подписавшему настоящий Протокол.

\section{Протокол № 4}

\section{к Конвенции о защите прав человека и основных свобод об обеспечении некоторых прав и свобод помимо тех, которые уже включены в Конвенцию и первый Протокол к ней}

г. Страсбург, 16.IX.1963 г.

Правительства, подписавшие настоящий Протокол, являющиеся членами Совета Европы,

преисполненные решимости принять меры по обеспечению коллективного осуществления некоторых прав и свобод помимо тех, которые уже включены в Раздел I Конвенции о защите прав человека и основных свобод, подписанной в Риме 4 ноября 1950 года (далее именуемой „Конвенция“), и в статьи 1, 2 и 3 первого Протокола к Конвенции, подписанного в Париже 20 марта 1952 года, согласились о нижеследующем:

\section{Статья 1}

\section{Запрещение лишения свободы за долги}

Никто не может быть лишен свободы лишь на том основании, что он не в состоянии выполнить какое-либо договорное обязательство. 


\section{Статья 2}

\section{Свобода передвижения}

1. Каждый, кто на законных основаниях находится на территории какого-либо Государства, имеет в пределах этой территории право на свободу передвижения и свободу выбора местожительства.

2. Каждый свободен покидать любую страну, включая свою собственную.

3. Пользование этими правами не подлежит никаким ограничениям, кроме тех, которые предусмотрены законом и необходимы в демократическом обществе в интересах национальной безопасности или общественного спокойствия, для поддержания общественного порядка, предотвращения преступлений, охраны здоровья или нравственности или для защиты прав и свобод других лиц.

4. Права, признанные в пункте 1, могут также, в определенных районах, подлежать ограничениям, вводимым в соответствии с законом и обоснованным общественными интересами в демократическом обществе.

\section{Статья 3}

\section{Запрещение высылки граждан}

1. Никто не может быть выслан путем индивидуальных или коллективных мер с территории Государства, гражданином которого он является.

2. Никто не может быть лишен права на въезд на территорию Государства, гражданином которого он является.

\section{Статья 4}

\section{Запрещение коллективной высылки иностранцев}

Коллективная высылка иностранцев запрещается.

\section{Территориальная сфера действия}

1. Любая Высокая Договаривающаяся Сторона может при подписании или ратификации настоящего Протокола или в любое время впоследствии направить Генеральному секретарю Совета Европы заявление о пределах своих обязательств относительно применения положений настоящего Протокола к тем указанным в заявлении территориям, за внешние сношения которых она несет ответственность.

2. Любая Высокая Договаривающаяся Сторона, направившая заявление в соответствии с положениями предыдущего пункта, может время от времени направлять новое заявление об изменении условий любого предыдущего заявления или о прекращении применения положений настоящего Протокола в отношении какой-либо территории.

3. Заявление, сделанное в соответствии с положениями настоящей статьи, рассматривается как сделанное в соответствии с пунктом 1 статьи 56 Конвенции.

4. Территория любого Государства, к которой настоящий Протокол применяется в силу его ратификации или принятия этим Государством, и каждая из территорий, к которой настоящий Протокол применяется в силу заявления этого Государства в соответствии с положениями настоящей статьи, рассматриваются как отдельные территории для целей ссылки на территорию Государства в статьях 2 и 3.

5. Любое Государство, сделавшее заявление в соответствии с пунктами 1 и 2 настоящей статьи, может впоследствии в любое время заявить, применительно к одной или нескольким территориям, указанным в этом заявлении, что оно признает компетенцию Суда принимать жалобы от физических лиц, неправительственных организаций или групп частных лиц, как это предусмотрено статьей 34 Конвенции, относительно соблюдения всех или любой из статей 1, 2, 3 и 4 настоящего Протокола. 


\section{Статья 6}

\section{Соотношение с Конвенцией}

Высокие Договаривающиеся Стороны рассматривают статьи 1, 2, 3, 4 и 5 настоящего Протокола как дополнительные статьи к Конвенции, и все положения Конвенции применяются соответственно.

\section{Статья 7}

\section{Подписание и ратификация}

1. Настоящий Протокол открытдля подписания Государствами - членами Совета Европы, подписавшими Конвенцию. Он подлежит ратификации одновременно с ратификацией Конвенции или после таковой. Протокол вступает в силу после сдачи на хранение пяти ратификационных грамот. В отношении любого подписавшего Государства, которое ратифицирует настоящий Протокол впоследствии, он вступает в силу с даты сдачи им на хранение его ратификационной грамоты.

2. Ратификационные грамоты сдаются на хранение Генеральному секретарю Совета Европы, который уведомляет все Государства - члены Совета Европы о Государствах, ратифицировавших Протокол.

В удостоверение чего нижеподписавшиеся, должным образом на то уполномоченные, подписали настоящий Протокол.

Совершено в Страсбурге 16 сентября 1963 года на английском и французском языках, причем оба текста имеют одинаковую силу, в единственном экземпляре, который хранится в архиве Совета Европы. Генеральный секретарь направляет заверенную копию каждому Государству, подписавшему настоящий Протокол.

\section{Протокол № 6}

\section{к Конвенции о защите прав человека и основных свобод относительно отмены смертной казни}

\author{
г. Страсбург, 28.IV.1983 г.
}

Государства - члены Совета Европы, подписавшие настоящий Протокол к Конвенции о защите прав человека и основных свобод, подписанной в Риме 4 ноября 1950 года (далее именуемой „Конвенция"),

считая, что развитие, имевшее место во многих Государствах - членах Совета Европы, выражает общую тенденцию в пользу отмены смертной казни, согласились о нижеследующем:

\section{Статья 1}

\section{Отмена смертной казни}

Смертная казнь отменяется. Никто не может быть приговорен к смертной казни или казнен.

\section{Статья 2}

\section{Применение смертной казни в военное время}

Государство может предусмотреть в своем законодательстве смертную казнь за деяния, совершенные в военное время или при неизбежной угрозе войны; подобное наказание применяется только в установленных законом случаях и в соответствии с его положениями. Государство сообщает Генеральному 
секретарю Совета Европы соответствующие положения этого законодательства.

\section{Статья 3}

\section{Запрещение отступлений от выполнения обязательств}

Отступления от положений настоящего Протокола на основании статьи 15 Конвенции не допускаются.

\section{Статья 4}

\section{Запрещение оговорок}

Оговорки в отношении положений настоящего Протокола на основании статьи 57 Конвенции не допускаются.

\section{Статья 5}

\section{Территориальная сфера действия}

1. Любое Государство может при подписании или сдаче им на хранение его ратификационной грамоты или документа о принятии или утверждении указать территорию или территории, на которые распространяется действие настоящего Протокола.

2. Любое Государство может впоследствии в любое время путем заявления, направленного на имя Генерального секретаря Совета Европы, распространить действие настоящего Протокола на любую другую территорию, указанную в заявлении. В отношении этой территории Протокол вступает в силу в первый день месяца, следующего за датой получения Генеральным секретарем заявления.

3. Любоезаявление, сделанное на основаниидвухпредыдущих пунктов и касающееся любой указанной в нем территории, может быть отозвано путем уведомления, направленного на имя Генерального секретаря. Отзыв вступает в силу с первого дня месяца, следующего за датой получения Генеральным секретарем этого уведомления.

\section{Статья 6}

\section{Соотношение с Конвенцией}

Государства-участники рассматривают статьи 1, 2, 3, 4 и 5 настоящего Протокола как дополнительные статьи к Конвенции, и все положения Конвенции применяются соответственно.

\section{Статья 7}

\section{Подписание и ратификация}

Настоящий Протокол открыт для подписания Государствами членами Совета Европы, подписавшими Конвенцию.Онподлежит ратификации, принятию или утверждению. Государство член Совета Европы не может ратифицировать, принять или утвердить настоящий Протокол без одновременной или предшествующей ратификации Конвенции. Ратификационные грамоты или документы о принятии или утверждении сдаются на хранение Генеральному секретарю Совета Европы.

\section{Статья 8}

\section{Вступление в силу}

1. Настоящий Протокол вступает в силу в первый день месяца, следующего за датой, на которую пять Государств - членов Совета Европы выразят свое согласие на обязательность для них Протокола в соответствии с положениями статьи 7.

2. Для любого Государства-члена, которое выразит впоследствии свое согласие на обязательность для него Протокола, он вступает в силу в первый день месяца, следующего за датой сдачи им на хранение его ратификационной грамоты или документа о принятии или утверждении. 


\section{Статья 9}

\section{Функции депозитария}

Генеральный секретарь Советы Европы уведомляет Государства - члены Совета Европы о:

(a) каждом подписании;

(b) сдаче на хранение каждой ратификационной грамоты или документа о принятии или утверждении;

(c) каждой дате вступления настоящего Протокола в силу в соответствии со статьями 5 и 8;

(d) каждом ином акте, уведомлении или сообщении, относящемся к настоящему Протоколу.

В удостоверение чего нижеподписавшиеся, должным образом на то уполномоченные, подписали настоящий Протокол.

Совершено в Страсбурге 28 апреля 1983 года на английском и французском языках, причем оба текста имеют одинаковую силу, в единственном экземпляре, который хранится в архиве Совета Европы. Генеральный секретарь Совета Европы направляет заверенную копию каждому Государству - члену Совета Европы.

\section{Протокол № 7}

\section{к Конвенции о защите прав человека и основных свобод}

г. Страсбург, 22.XI.1984 г.

Государства - члены Совета Европы, подписавшие настоящий Протокол,

преисполненные решимости принять дальнейшие меры по обеспечению коллективного осуществления некоторых прав и свобод посредством применения Конвенции о защите прав человека и основных свобод, подписаннойв Риме 4 ноября 1950 года (далее именуемой „Конвенция“),

согласились о нижеследующем:

\section{Статья 1}

\section{Процедурные гарантии в случае высылки иностранцев}

1. Иностранец, на законных основаниях проживающий на территории какого-либо Государства, не может быть выслан из него иначе как во исполнение решения, принятого в соответствии с законом, и должен иметь возможность:

(a) представить аргументы против его высылки,

(b) требовать пересмотра его дела, и

(c) для этих целей быть представленным перед компетентным органом или перед одним или несколькими лицами, назначенными таким органом. 
2. Иностранец может быть выслан до осуществления его прав, перечисленных в подпунктах „а", „b" и "c" пункта 1 настоящей статьи, если такая высылка необходима в интересах общественного порядка или обусловлена соображениями национальной безопасности.

\section{Статья 2}

Право на обжалование приговоров

\section{по уголовным делам во второй инстанции}

1. Каждый осужденный за совершение уголовного преступления имеет право на то, чтобы вынесенный в отношении него приговор или определенное ему наказание были пересмотрены вышестоящей судебной инстанцией. Осуществление этого права, включая основания, на которых оно может быть осуществлено, регулируется законом.

2. Из этого права могут делаться исключения в отношении незначительных правонарушений, признанных таковыми законом, или когда соответствующее лицо было судимо уже в первой инстанции верховным судом или признано виновным и осуждено в результате судебного пересмотра его оправдания.

\section{Статья 3}

\section{Компенсация в случае судебной ошибки}

Если какое-либо лицо на основании окончательного приговора было осуждено за совершение уголовного преступления, а вынесенный ему приговор впоследствии был отменен, или оно было помиловано на том основании, что какое-либо новое или вновь открывшееся обстоятельство убедительно доказывает, что имела место судебная ошибка, то лицо, понесшее наказание в результате такого осуждения, получает компенсацию согласно закону или существующей практике соответствующего
Государства, если только не будет доказано, что ранее неизвестное обстоятельство не было своевременно обнаружено полностью или частично по его вине.

\section{Статья 4}

\section{Право не быть судимым или наказанным дважды}

1. Никто не должен быть повторно судим или наказан в уголовном порядке в рамках юрисдикции одного и того же Государства за преступление, за которое уже был оправдан или осужден в соответствии с законом и уголовно-процессуальными нормами этого Государства.

2. Положения предыдущего пункта не препятствуют повторному рассмотрению дела в соответствии с законом и уголовно-процессуальными нормами соответствующего Государства, если имеются сведения о новых или вновь открывшихся обстоятельствах или если в ходе предыдущего разбирательства были допущены существенные нарушения, повлиявшие на исход дела.

3. Отступления от выполнения настоящей статьи на основании положений статьи 15 Конвенции не допускаются.

\section{Статья 5}

\section{Равноправие супругов}

Супруги обладают равными правами и несут равную гражданско-правовую ответственность в отношениях между собой и со своими детьми в том, что касается вступления в брак, пребывания в браке и при его расторжении. Настоящая статья не препятствует Государствам принимать такие меры, которые необходимы для соблюдения интересов детей. 


\section{Статья 6}

\section{Территориальная сфера действия}

1. Любое Государство может при подписании или сдаче им на хранение его ратификационной грамоты или документа о принятии или утверждении указать территорию или территории, на которые распространяется действие настоящего Протокола, и указать, в каких пределах оно обязуется применять положения настоящего Протокола к этой территории или этим территориям.

2. Любое Государство может впоследствии в любое время, путем направления заявления Генеральному секретарю Совета Европы, распространить применение настоящего Протокола на любую другую территорию, указанную в заявлении. Протокол вступает в силу в отношении этой территории в первый день месяца, следующего по истечении двух месяцев с даты получения Генеральным секретарем заявления.

3. Любоезаявление, сделанное на основании двухпредыдущих пунктов и касающееся любой указанной в нем территории, может быть отозвано или изменено путем уведомления Генерального секретаря Совета Европы. Отзыв или изменение вступает в силу в первый день месяца, следующего по истечении двух месяцев с даты получения Генеральным секретарем уведомления.

4. Заявление, сделанное в соответствии с положениями настоящей статьи, рассматривается как сделанное в соответствии с пунктом 1 статьи 56 Конвенции.

5. Территория любого Государства, к которой настоящий Протокол применяется в силу его ратификации, принятия или утверждения этим Государством, и каждая из территорий, к которой настоящий Протокол применяется в силу заявления этого Государства в соответствии с положениями настоящей статьи, могут рассматриваться как отдельные территории для целей ссылки на территорию Государства в статье 1.
6. Любое Государство, сделавшее заявление в соответствии с пунктами 1 или 2 настоящей статьи, может впоследствии в любое время заявить, применительно к одной или нескольким территориям, указанным в этом заявлении, что оно признает компетенцию Суда принимать жалобы от физических лиц, неправительственных организаций или групп частных лиц, как это предусмотрено статьей 34 Конвенции, относительно соблюдения статей 1, 2, 3, 4 и 5 настоящего Протокола.

\section{Статья 7}

\section{Соотношение с Конвенцией}

Государства-участники рассматривают статьи 1, 2, 3, 4, 5 и 6 настоящего Протокола как дополнительные статьи к Конвенции, и все положения Конвенции применяются соответственно.

\section{Статья 8 \\ Подписание и ратификация}

Настоящий Протокол открыт для подписания Государствами членами Совета Европы, подписавшими Конвенцию.Онподлежит ратификации, принятию или утверждению. Государство член Совета Европы не может ратифицировать, принять или утвердить настоящий Протокол без предшествующей или одновременной ратификации Конвенции. Ратификационные грамоты или документы о принятии или утверждении сдаются на хранение Генеральному секретарю Совета Европы.

\section{Статья 9}

\section{Вступление в силу}

1. Настоящий Протокол вступает в силу в первый день месяца, следующего по истечении двух месяцев с даты, когда семь Государств - членов Совета Европы выразят свое 
согласие на обязательность для них Протокола в соответствии с положениями статьи 8.

2. Для любого Государства-члена, которое выразит впоследствии свое согласие на обязательность для него Протокола, он вступает в силу в первый день месяца, следующего по истечении двух месяцев с даты сдачи им на хранение его ратификационной грамоты или документа о принятии или утверждении.

\section{Статья 10}

\section{Функции депозитария}

Генеральный секретарь Совета Европы уведомляет все Государства - члены Совета Европы о:

(a) каждом подписании;

(b) сдаче на хранение каждой ратификационной грамоты или документа о принятии или утверждении;

(c) каждой дате вступления настоящего Протокола в силу в соответствии со статьями 6 и 9;

(d) каждом ином акте, уведомлении или заявлении относящемся к настоящему Протоколу.

В удостоверение чего нижеподписавшиеся, должным образом на то уполномоченные, подписали настоящий Протокол.

Совершено в Страсбурге 22 ноября 1984 года на английском и французском языках, причем оба текста имеют одинаковую силу, в единственном экземпляре, который хранится в архиве Совета Европы. Генеральный секретарь Совета Европы направляет заверенную копию каждому Государству - члену Совета Европы.

\section{Протокол № 12}

\section{к Конвенции о защите прав человека и основных свобод}

Рим, 4.XI.2000 г.

Государства - члены Совета Европы, подписавшие настоящий Протокол,

принимая во внимание основополагающий принцип, согласно которому все люди равны перед законом и имеют право на равную защиту со стороны закона;

преисполненные решимости предпринять дальнейшие шаги по обеспечению равенства всех людей путем коллективного осуществления общего запрещения дискриминации на основании Конвенции о защите прав человека и основных свобод, подписанной в Риме 4 ноября 1950 года (далее именуемой „Конвенция");

подтверждая, что принцип недискриминации не препятствует Государствам-участникам принимать меры для обеспечения полного и эффективного равенства при условии объективной и разумной обоснованности таких мер,

согласились о нижеследующем:

\section{Статья 1}

\section{Общее запрещение дискриминации}

1. Пользование любым правом, установленным законом должно быть обеспечено без какой бы то ни было дискриминации по признаку пола, расы, цвета кожи, языка 
религии, политических или иных убеждений, национального или социального происхождения, принадлежности к национальным меньшинствам, имущественного положения, рождения или по любым иным признакам.

2. Никто не может быть подвергнут дискриминации со стороны каких бы то ни было публичных властей по признакам, упомянутым в пункте 1 настоящей статьи.

\section{Статья 2}

\section{Территориальная сфера действия}

1. Любое Государство при подписании или сдаче на хранение ратификационной грамоты или документа о принятии или утверждении может указать территорию или территории, на которые распространяется действие настоящего Протокола.

2. Любое Государство впоследствии в любое время может путем заявления, направленного Генеральному секретарю Совета Европы, распространить действие настоящего Протокола на любую другую территорию, указанную в заявлении. Протокол вступает в силу в отношении этой территории в первый день месяца, следующего по истечении трех месяцев с даты получения Генеральным секретарем заявления.

3. Любоезаявление, сделанное на основании двухпредыдущих пунктов и касающееся любой указанной в нем территории, может быть отозвано или изменено путем уведомления, направленного на имя Генерального секретаря. Отзыв или изменение вступают в силу в первый день месяца, следующего по истечении трех месяцев с даты получения Генеральным секретарем уведомления.

4. Заявление, сделанное в соответствии с положениями настоящей статьи, рассматривается как сделанное в соответствии с пунктом 1 статьи 56 Конвенции.

5. Любое Государство, сделавшее заявление в соответствии с пунктами 1 или 2 настоящей статьи, может впоследствии в любое время заявить применительно к одной или нескольким территориям, указанным в этом заявлении, что оно признает компетенцию Суда принимать жалобы от физических лиц, неправительственных организаций или групп частных лиц, как это предусмотрено статьей 34 Конвенции, в отношении статьи 1 настоящего Протокола.

\section{Статья 3 \\ Соотношение с Конвенцией}

Государства-участники рассматривают статьи 1 и 2 настоящего Протокола как дополнительные статьи к Конвенции, и все положения Конвенции применяются соответственно.

\section{Статья 4}

\section{Подписание и ратификация}

Настоящий Протокол открыт для подписания Государствами членами Совета Европы, подписавшими Конвенцию.Онподлежит ратификации, принятию или утверждению. Государство член Совета Европы не может ратифицировать, принять или утвердить настоящий Протокол без одновременной или предшествующей ратификации Конвенции. Ратификационные грамоты или документы о принятии или утверждении сдаются на хранение Генеральному секретарю Совета Европы.

\section{Статья 5}

\section{Вступление в силу}

1. Настоящий Протокол вступает в силу в первый день месяца, следующего по истечении трех месяцев с даты, когда десять Государств - членов Совета Европы выразят свое согласие на обязательность для них настоящего Протокола в соответствии с положениями статьи 4. 
2. Для любого Государства-члена, которое впоследствии выразит свое согласие на обязательность для него настоящего Протокола, он вступает в силу в первый день месяца, следующего по истечении трех месяцев с даты сдачи на хранение ратификационной грамоты или документа о принятии или утверждении.

\section{Статья 6}

\section{Функции депозитария}

Генеральный секретарь Совета Европы уведомляет все Государства - члены Совета Европы о:

(a) каждом подписании;

(b) сдаче на хранение каждой ратификационной грамоты или документа о принятии или утверждении;

(c) каждой дате вступления настоящего Протокола в силу в соответствии со статьями 2 и 5;

(d) каждом ином акте, уведомлении или сообщении, относящемся к настоящему Протоколу.

В удостоверение чего нижеподписавшиеся, должным образом на то уполномоченные, подписали настоящий Протокол.

Совершено в Риме 4 ноября 2000 года на английском и французском языках, причем оба текста имеют одинаковую силу, в единственном экземпляре, который хранится в архиве Совета Европы. Генеральный секретарь Совета Европы направляет заверенную копию каждому Государству - члену Совета Европы.

\section{Протокол № 13}

\section{к Конвенции о защите прав человека и основных свобод относительно отмены смертной казни в любых обстоятельствах}

\author{
Вильнюс, 3.V.2002 г.
}

Государства - члены Совета Европы, подписавшие настоящий Протокол,

будучи убеждены, что право каждого человека на жизнь является основополагающей ценностью в демократическом обществе, и что отмена смертной казни является основным условием защиты этого права и полного признания достоинства, присущего каждому человеку;

желая усилить защиту права на жизнь, гарантированного Конвенцией о защите прав человека и основных свобод, подписанной в Риме 4 ноября 1950 года (далее именуемой „Конвенция");

отмечая, что Протокол № 6 к Конвенции, касающийся отмены смертной казни, подписанный в Страсбурге 28 апреля 1983 года, не исключает применения смертной казни за действия, совершенные в военное время или при неизбежной угрозе войны;

преисполненные решимости сделать последний шаг с целью отмены смертной казни в любых обстоятельствах, 
3. Любое заявление, сделанное согласно двум предыдущим пунктам в отношении любой территории, указанной в таком заявлении, может быть отозвано или изменено посредством уведомления, адресованного Генеральному секретарю. Отзыв или изменение вступают в силу в первый день месяца, следующего по истечении трёх месяцев с даты получения Генеральным секретарём такого уведомления.

\section{Статья 2}

\section{Статья 5}

\section{Запрещение отступлений от выполнения обязательств}

Отступления от положений настоящего Протокола на основании статьи 15 Конвенции не допускаются.

\section{Статья 3}

\section{Запрещение оговорок}

Оговорки в отношении положений настоящего Протокола на основании статьи 57 Конвенции не допускаются.

\section{Статья 4}

\section{Территориальная сфера действия}

1. Любое Государство может при подписании или сдаче на хранение своей ратификационной грамоты или документа о принятии или утверждении указать территорию или территории, к которым применяется настоящий Протокол.

2. Любое Государство может впоследствии в любой момент путем заявления, направленного на имя Генерального секретаря Совета Европы, распространить действие настоящего Протокола на любую другую территорию, указанную в заявлении. В отношении этой территории Протокол вступает в силу в первый день месяца, следующего по истечении трех месяцев с даты получения Генеральным секретарем заявления. 
2. Для любого Государства-члена, которое впоследствии выразит свое согласие на обязательность для него настоящего Протокола, он вступает в силу в первый день месяца, следующего по истечении трех месяцев с даты сдачи на хранение ратификационной грамоты или документа о принятии или утверждении.

\section{Статья 8}

\section{Функции депозитария}

Генеральный секретарь Совета Европы уведомляет все Государства - члены Совета Европы о:

(a) каждом подписании;

(b) сдаче на хранение каждой ратификационной грамоты или документа о принятии или утверждении;

(c) каждой дате вступления настоящего Протокола в силу в соответствии со статьями 4 и 7;

(d) каждом ином действии, уведомлении или сообщении, относящемся к настоящему Протоколу.

В удостоверение чего нижеподписавшиеся, должным образом на то уполномоченные, подписали настоящий Протокол.

Совершено в Вильнюсе 3 мая 2002 года на английском и французском языках, причем оба текста имеют одинаковую силу, в единственном экземпляре, который хранится в архиве Совета Европы. Генеральный секретарь Совета Европы направляет заверенную копию каждому Государству - члену Совета Европы.

\section{Протокол № 16}

\section{к Конвенции о защите прав человека и основных свобод}

\author{
Страсбург, 2.X.2013 г.
}

Государства-члены Совета Европы и другие Высокие Договаривающиеся Стороны Конвенции о защите прав человека и основных свобод, подписанной в Риме 4 ноября 1950 года (далее именуемой «Конвенция»), подписавшие настоящий Протокол,

принимая во внимание положения Конвенции и, в частности, статьи 19, учреждающей Европейский Суд по правам человека (далее именуемый «Суд»);

учитывая, что расширение полномочий Суда по вынесению консультативных заключений будет способствовать дальнейшему укреплению взаимодействия между Судом и национальными властями и тем самым обеспечит более эффективное применение Конвенции в соответствии с принципом субсидиарности;

принимая во внимание Заключение № 285 (2013) Парламентской ассамблеи Совета Европы, принятое 28 июня 2013 года, 


\section{Статья 3}

\section{Статья 1}

1. Высшие суды и трибуналы Высокой Договаривающейся Стороны, определяемые в соответствии со статьей 10, могут запрашивать у Суда консультативные заключения по ключевым вопросам, касающимся толкования или применения прав и свобод, закрепленных в Конвенции и Протоколах к ней.

2. Запрашивающий суд или трибунал может обратиться за консультативным заключением только в связи с делом, находящимся на его рассмотрении.

3. Запрашивающий суд или трибунал должен мотивировать свой запрос и представить юридические и фактические обстоятельства, имеющие значение для рассматриваемого им дела.

\section{Статья 2}

1. Коллегия в составе пяти судей Большой Палаты принимает решение о том, удовлетворять ли запрос о вынесении консультативного заключения, с учетом положений статьи 1. Коллегия должна мотивировать решение об отказе в удовлетворении запроса.

2. Если Коллегия удовлетворяет запрос, Большая Палата должна вынести консультативное заключение.

3. В состав Коллегии и Большой Палаты, упомянутых в предшествующих пунктах, входит ех оfficio судья, избранный от Высокой Договаривающейся Стороны, к которой относится запрашивающий суд или трибунал. В случае отсутствия такого судьи или если он не может участвовать в заседании, в качестве судьи по делу заседает лицо, назначенное Председателем Суда из списка, заблаговременно представленного этой Стороной.
Комиссар Совета Европы по правам человека и Высокая Договаривающая Сторона, к которой относится запрашивающий суд или трибунал, вправе представлять письменные замечания и принимать участие в слушаниях. В интересах надлежащего отправления правосудия Председатель Суда может также предложить любой другой Высокой Договаривающейся Стороне или лицу представить письменные замечания или принять участие в слушаниях.

\section{Статья 4}

1. Консультативные заключения должны

быть мотивированными.

2. Если консультативное заключение в целом или частично не выражает единогласного мнения судей, то любой судья вправе представить свое особое мнение.

3. Консультативные заключения направляются запрашивающему суду или трибуналу и Высокой Договаривающейся Стороне, к которой относится этот суд или трибунал.

4. Консультативные заключения подлежат опубликованию.

\section{Статья 5}

Консультативные заключения не имеют обязательной силы.

\section{Статья 6}

Высокие Договаривающиеся Стороны рассматривают статьи 1-5 настоящего Протокола как дополнительные статьи к Конвенции, и все положения Конвенции применяются соответственно. 


\section{Статья 7}

1. Настоящий Протокол открыт для подписания Высокими Договаривающимися Сторонами Конвенции, которые могут выразить свое согласие на его обязательность для них путем:

(а) подписания без условия о ратификации, принятии или утверждении; или

(b) подписания под условием ратификации, принятия или утверждения, с последующей ратификацией, принятием или утверждением.

2. Ратификационные грамоты и документы о принятии или утверждении сдаются на хранение Генеральному секретарю Совета Европы.

\section{Статья 8}

1. Настоящий Протокол вступает в силу в первый день месяца, следующего по истечении трех месяцев, считая с даты, когда десять Высоких Договаривающихся Сторон Конвенции выразили свое согласие на обязательность для них Протокола в соответствии с положениями статьи 7.

2. В отношении любой Высокой Договаривающейся Стороны Конвенции, которая впоследствии выразит свое согласие на обязательность для нее Протокола, он вступает в силу в первый день месяца, следующего по истечении трех месяцев, считая с даты выражения ей своего согласия на обязательность для нее Протокола в соответствии с положениями статьи 7.

\section{Статья 9}

Применительно к положениям настоящего Протокола не допускаются оговорки, о которых идет речь в статье 57 Конвенции.

\section{Статья 10}

При подписании или сдаче на хранение своей ратификационной грамоты или документа о принятии или утверждении каждая Высокая Договаривающаяся Сторона Конвенции должна указать путем направления заявления Генеральному секретарю Совета Европы суды или трибуналы, которые она определяет для целей пункта 1 статьи 1 настоящего Протокола. Данное заявление может впоследствии быть изменено в любое время тем же образом.

\section{Статья 11}

Генеральный секретарь Совета Европы уведомляет Государствачлены Совета Европы и другие Высокие Договаривающиеся Стороны Конвенции о:

(a) каждом подписании;

(b) сдаче на хранение каждой ратификационной грамоты или документа о принятии или утверждении;

(c) каждой дате вступления в силу настоящего Протокола в соответствии со статьей 8 ;

(d) каждом заявлении, поданном в соответствии со статьей 10; и

(е) каждом ином акте, уведомлении или сообщении, относящемся к настоящему Протоколу.

В удостоверение чего нижеподписавшиеся, должным образом на то уполномоченные, подписали настоящий Протокол.

Совершено в Страсбурге 2 октября 2013 года на английском и французском языках, причем оба текста имеют одинаковую силу, в единственном экземпляре, который хранится в архиве Совета Европы. Генеральный секретарь Совета Европы направляет заверенную копию каждому Государству-члену Совета Европы и другим Высоким Договаривающимся Сторонам Конвенции. 


\section{Европейская конвенция по правам человека}

European Court of Human Rights Council of Europe 67075 Strasbourg cedex France 